\title{
Estimation of Food Consumption in Adélie Penguin Chicks Using Body Mass and Growth
}

\author{
Yutaka Watanuki $^{1), *}$, Akiko Kato ${ }^{1)}$, and Graham Robertson ${ }^{2)}$
}

\begin{abstract}
Food consumption by penguins is an important component of energy flow in southern ocean food chain. We present a simple method for estimating daily food consumption of Adélie penguin Pygoscelis adeliae chicks by weighing them at regular intervals. Assuming that chick mass decrease rate is constant during food absorption period, their daily food consumption could be estimated by their initial mass and daily growth. Our method would be useful for estimating food consumption of individual chicks handled for other purposes with little additional disturbance.
\end{abstract}

Key words: Penguin chicks, Food consumption, Antarctica, Serial weighing

\section{Introduction}

The capacity of adult penguins to satisfy the food requirements of growing chicks is an important aspect of parental investment and has a direct affect on the reproductive performance. Knowledge of the food consumption rates of Antarctic penguin chicks is therefore of fundamental importance to ecologists seeking to understand the dynamics of the southern ocean food chain.

The food consumption of penguin chicks has been estimated by various techniques, including the measurement of energy expenditure (by oxygen consumption) and the metabolizable energy density of the diet (Taylor 1985, Brown 1987, Culick et al. 1990), the measurement of water and sodium turnover rates (Robertson et al. 1988), and by the serial weighing of chicks (Williams 1982, Lishman 1985). Measurement of energy expenditure by using metabolism chambers or stable isotopes cause disturbance on breeding procedure of penguins and these methods are expensive. Serial weighing of chicks at short time intervals (3-hr, Lishman 1985 for example) could cause disturbance if we apply this technique for entire chick rearing period. We suggest here a modification of the last method to estimate food consumption of Adélie penguin Pygoscelis adeliae chicks based on measurements of chick mass and growth rate made at 24-hr interval during the chick growing period. We examine the relationship between these two variables and food consumption for penguin chicks at two localities where adult attendance pattern were markedly different.

Received 11 July 1994, Revised 12 September 1994, Accepted 27 September 1994.

1) National Institute of Polar Research, 1-9 Kaga 1-chome, Itabashi-ku, Tokyo 173, Japan.

2) Australian Antarctic Division, Channel Highway, Kingston, Tasmania 7050, Australia.

* Current address: Laboratory of Applied Zoology, Faculty of Agriculture, Hokkaido University, Kita-9 Nishi-9, Kita-ku, Sapporo 060, Japan. 
Table 1. Mean and SD of chick mass at the start of observation (kg), estimated daily food consumption $(\mathrm{kg})$ and daily growth $(\mathrm{kg})$ of Adélie penguin chicks at two localities.

\begin{tabular}{lccccccc}
\hline \hline \multirow{2}{*}{ Date } & \multicolumn{3}{c}{ Hukuro Cove } & & \multicolumn{3}{c}{ Magnetic I. } \\
\cline { 2 - 3 } \cline { 7 - 8 } & 4-5 Jan. & $14-15$ Jan. & 23-24 Jan. & & 1 Jan. & 11 Jan. & 21 Jan. \\
\hline No. of chicks & $12(9)$ & $12(8)$ & $8(6)$ & & $9(8)$ & $9(8)$ & $8(8)$ \\
Chick mass (kg) & $0.95 \pm 0.36$ & $1.60 \pm 0.40$ & $2.93 \pm 0.54$ & & $0.41 \pm 0.24$ & $1.52 \pm 0.45$ & $2.74 \pm 0.48$ \\
Food consumption (kg/day) & $0.23 \pm 0.07$ & $0.57 \pm 0.20$ & $0.65 \pm 0.34$ & & $0.16 \pm 0.11$ & $0.30 \pm 0.13$ & $0.47 \pm 0.32$ \\
Growth (kg/day) & $-0.01 \pm 0.06$ & $0.20 \pm 0.23$ & $-0.04 \pm 0.25$ & & $0.02 \pm 0.11$ & $0.01 \pm 0.19$ & $-0.11 \pm 0.35$ \\
\hline
\end{tabular}

No. of sample chicks are shown with the no. of nests in parentheses.

\section{Materials and Methods}

The study was conducted at the Hukuro Cove colony (150-200 breeding pairs: $69^{\circ}$ $\left.00^{\prime} \mathrm{S} 39^{\circ} 39^{\prime} \mathrm{E}\right)$ in Lüzow-Holm Bay in January 1991 and a colony (5,000 pairs, Woehler et al. 1989) at Magnetic Island (68 $\left.33^{\prime} \mathrm{S} 77^{\circ} 54^{\prime} \mathrm{E}\right)$ in Prydz Bay in January 1993. Fast sea-ice remained throughout the summer in Lützow-Holm Bay but broke out in mid January in Prydz Bay. During guarding and early creche stage, each parent brought 270 $\mathrm{g}$ food to the colony 0.8 times per day on average at Hukuro Cove and $530 \mathrm{~g}$ food 0.3 times per day on average at Magnetic I. (Watanuki et al. 1993 and unpublished data). At both colonies meals were dominated by Antarctic krill Euphausia superba. Parents fed chicks one to several times after returning from feeding trips at sea.

Food consumption per day was estimated by accumulating the increase in chick mass at each meal. As we did not know chick mass just before they were fed, we estimated it using the mass at the previous weighing and the mass decrease rate during food absorption period. The accumulation of food consumption for $24 \mathrm{hr}$. was defined as "daily food consumption". The mass difference between the start and the end of each observation day was defined as "daily growth".

Eight to twelve chicks of mostly single broods were selected in the edge of the colonies and marked on the flipper with numbered plastic tags. They were watched continuously and weighed with a pesola spring balance $( \pm 10 \mathrm{~g})$ every $3 \mathrm{hr}$. for $24 \mathrm{hr}$. on non consecutive three days at each colony (Table 1). In addition, they were weighed within $5 \mathrm{~min}$. after being fed by parents. The relationship between food consumption, growth and initial mass of single brood chicks and double brood chicks was assumed not to differ as mass specific energy expenditure and energy assimilation efficiency could not differ between them. Chick age was not determined but ranged from 5-10 days age (brooding stage) to 20-30 days age (early creche stage) based on their mass (Table 1). An observation started at 12:00 LST at Hukuro Cove and 0:00 LST at Magnetic Island.

Since existence metabolic rate (measured by oxygen consumption) of resting penguin chicks is related to an exponent of body mass of 0.92-1.11 (Brown 1987, Culick et al. 1990), food required for existence metabolism was assumed to be linearly dependent on body mass. In addition, mass based tissue production efficiency was assumed to be mass independent. Hence, we used a multiple linear regression model for estimating daily food consumption (F) by the chick mass at the start of observation (M) and daily growth (G); 
Hukuro Cove 4-5 Jan.

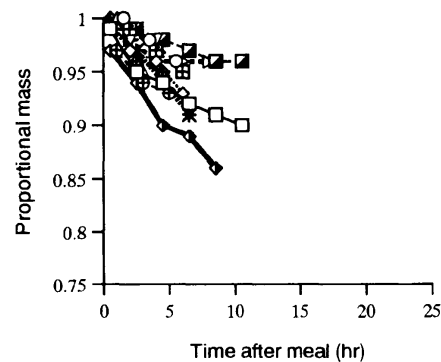

Magnetic I. 1 Jan.

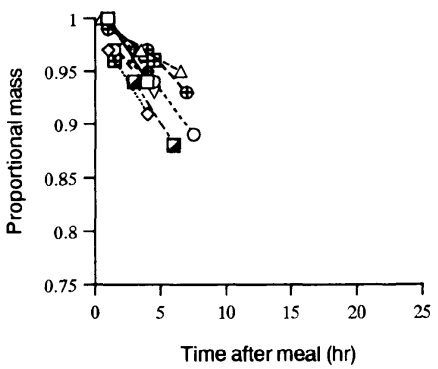

Hukuro Cove 14-15 Jan.

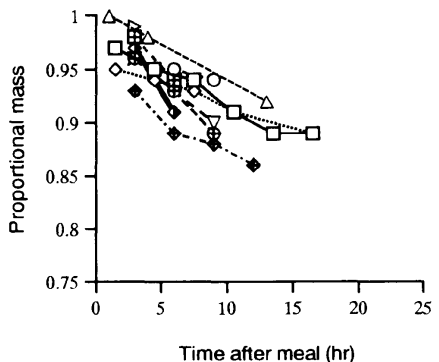

Magnetic I. 11 Jan.

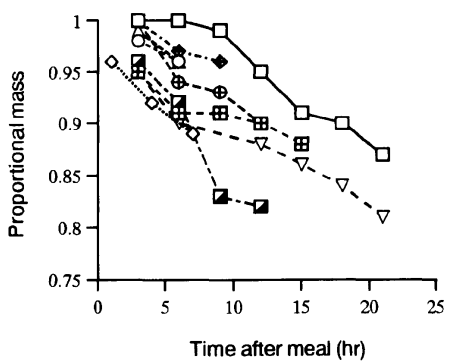

Hukuro Cove 23-24 Jan.

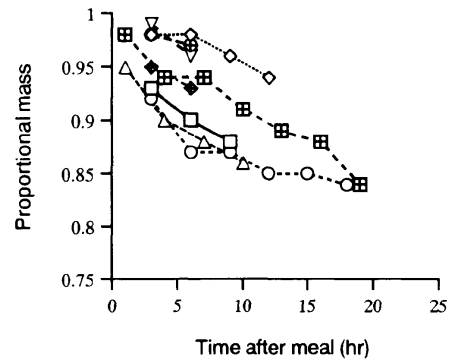

Magnetic I. 21 Jan.

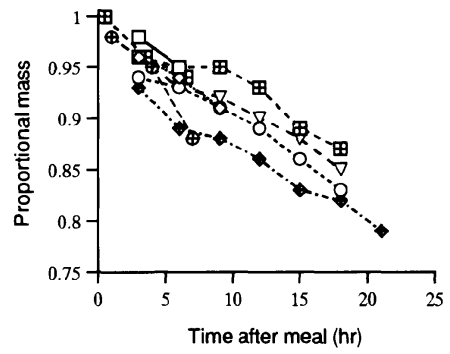

Fig. 1. Mass change of chicks after meals during the longest food absorption period shown as the proportion of the mass just after meals. Each symbol indicates individual chick.

$\mathbf{F}=a+b \mathbf{M}+c \mathbf{G}$

\section{Results}

Mass decrease during the longest food absorption period for each chick is shown as proportional mass change in Fig. 1. As mass decrease was almost linear, we assumed linear mass loss for simplyfing calculation, though Ricketts and Prince (1984) assumes both linear and exponential rates of mass loss in chicks of albatrosses (Diomedia chrysostoma and D. melanophris). As mass decrease rate (MDR) varied between individual chicks (Fig. 1), we used a slope of linear regression as a MDR for each chick to estimate its daily food consumption (F). F was estimated by using serial mass changes of chicks and these MDRs. Standard error (SE) of MDRs varied between $0 \mathrm{~g} / \mathrm{hr}$ and $10 \mathrm{~g} / \mathrm{hr}$ across individuals. Variance of $F$ could be calculated by using variance of MDRs and time between previous weighing and meals. SE of $F$ was $0-67 \mathrm{~g}$ (14.4 $\mathrm{g}$ on average).

Mass decrease rate (MDR $\mathrm{g} / \mathrm{hr}$ ) was greater for heavier chicks (Fig. 2: $\mathrm{MDR}=1.36$ $+9.25 \mathrm{M}, r^{2}=0.54, P<0.01$ for Hukuro Cove; $\mathrm{MDR}=2.92+8.18 \mathrm{M}, r^{2}=0.66, P<0.01$ for Magnetic I.: M, mass in kg). There was negative correlation between chick mass at the start of observation and daily growth at Magnetic I $\left(r^{2}=0.21, P<0.01\right)$ but the correlation was not significant at Hukuro Cove $\left(r^{2}=0.11\right.$, NS., Fig. 2). 


\section{Mass vs growth}
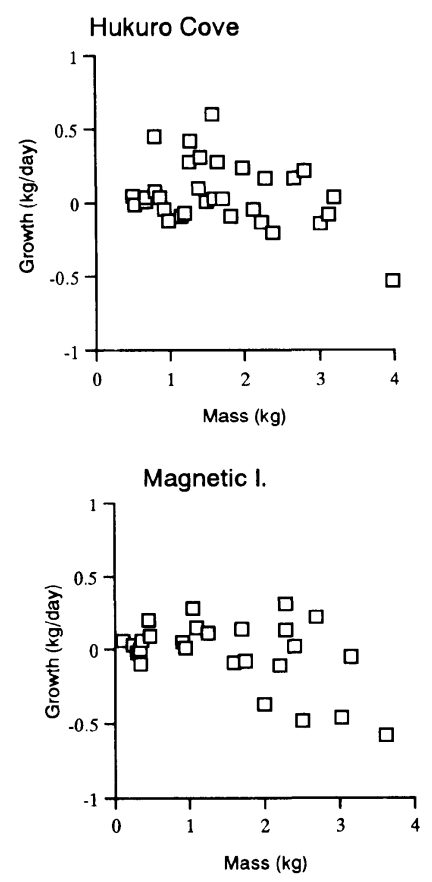

Mass vs mass decrease

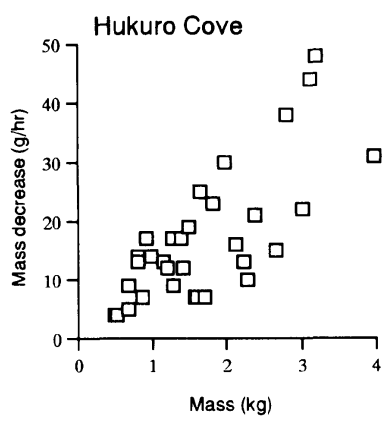

Magnetic I.

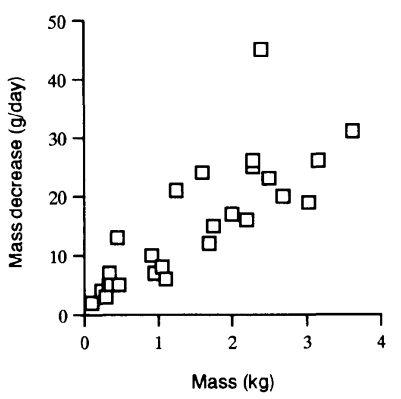

Fig. 2. Relationship between initial mass of chicks and their daily growth (left) and that between initial mass of chicks and their mass decrease rate during food absorption period (right) at Hukuro Cove and Magnetic I. colonies.

Multiple regression equations took the form;

Hukuro Cove; $\mathrm{F}=0.013( \pm 0.058)+0.230( \pm 0.030) \mathrm{M}+0.990( \pm 0.121) \mathrm{G}$

Magnetic I.; $\quad \mathbf{F}=0.038( \pm 0.028)+0.192( \pm 0.017) \mathrm{M}+0.988( \pm 0.075) \mathrm{G}$

Combined; $\quad \mathbf{F}=0.023( \pm 0.032)+0.214( \pm 0.017) \mathrm{M}+1.013( \pm 0.073) \mathrm{G}$.

where partial regression coefficients for the mass at the start of observation $(\mathbf{M ~ k g})$, that for daily growth ( $\mathrm{G} \mathrm{kg}$ ) on daily food consumption ( $\mathrm{F} \mathrm{kg}$ ) are shown with its standard errors in parentheses. Coefficient of multiple determination was $77 \%, 90 \%$ and $84 \%$ for Hukuro Cove, Magnetic I, and combined data, respectively. All the partial regression coefficients excluding those for constant are significantly different from 0 ( $t$-test, $P<0.01)$. The $95 \%$ confidence limits of partial regression coefficient for $M(0.17-0.29$ for Hukuro Cove and 0.16-0.23 for Magnetic I.) and G (0.75-1.11 for Hukuro Cove and 0.84-1.14 for Magnetic I.) overlapped greatly between Hukuro Cove and Magnetic I.

\section{Discussion}

Our measurement of daily food consumption (F) contained errors caused by within 
individual variation of mass decrease rates (MDR) in estimating the chick mass at meal times. The $95 \%$ confidence limit of $F$ for each chick was $0-132 \mathrm{~g}$ (30 g on average) which was equivalent to $0-31 \%$ of $F$ ( $8 \%$ on average). Considering $\pm 10 \mathrm{~g}$ spring scale accuracy, these errors could not greatly affect our conclusion.

The plausibility of the partial regression coefficients could be tested by comparing daily existence energy expenditure estimated using these regression equations with the energy expenditure estimated by other techniques. Daily energy expenditure of an active and a resting $1 \mathrm{~kg}$ Adélie penguin chicks, measured by oxygen consumption in a chamber, is $839.7 \mathrm{~kJ}$ and $723.6 \mathrm{~kJ}$, respectively (Culick et al. 1990). Assuming no growth, diet composition of $72 \%$ krill and $28 \%$ fish at Hukuro Cove and $100 \%$ krill at Magnetic I., (Watanuki et al. 1993 and unpublished data), diet energy density of $4.35 \mathrm{~kJ} / \mathrm{gwet}$ for krill and $3.97 \mathrm{~kJ} / \mathrm{gwet}$ for fish (Croxall et al. 1985) and food assimilation rate of 75\%, (Cooper 1977, Jackson 1986), our equation gives estimated daily existence energy of $773 \mathrm{~kJ}$ at Hukuro Cove and $740 \mathrm{~kJ}$ at Magnetic I. for a $1 \mathrm{~kg}$ chick. So, our estimation is similar to that of resting chicks estimated by oxygen consumption.

The partial correlation coefficient for daily growth in our equation, however, is a little different from that predicted by other studies of the energy requirements of birds. Assuming 1) energy based tissue production efficiency (total energy required to produce unit energy of body tissue) as $75 \%$ (Ricklefs 1974), 2) whole body tissue energy density of penguin chicks as 5.6-7.3 kJ/gwet (Brown 1987: data for Macaroni Eudyptes chrysolophus and Rockhopper $E$. chrysocome penguin chicks) and 3) mean energy value of food as $4.24 \mathrm{~kJ} /$ gwet at Hukuro Cove and $4.35 \mathrm{~kJ} /$ gwet at Magnetic I., chicks should receive 1.7-2.3 $\mathrm{g}$ food for $1 \mathrm{~g}$ tissue accumulation. Using our regression, however, chicks received about $1 \mathrm{~g}$ food for $1 \mathrm{~g}$ growth assuming no existence metabolism. This difference might be caused by our relatively short observation period $(24 \mathrm{hr})$ which may be too short for reliable estimation of tissue production efficiency. Another possible reason may be that some parts of energy needed for tissue accumulation were confounded with constant or resting metabolism in the multiple linear regression analyses.

Although our method contains some errors and the partial correlation coefficient is not concordant with the previously reported tissue production efficiency, it has an utilty as a simple method. With this method, we could decrease the frequency of weighing of chicks for estimating their food consumption. So we could estimate food consumption of many chicks already being handled for other purposes, such as measuring parental foraging effort, with little additional disturbance. In addition the equation may be applied to Adélie penguin populations in general because the partial correlation coefficients were similar for both localities where adult's nest attendance pattern differed greatly.

\section{Acknowledgments}

This work was supported by the 31st and the 32nd JARE and 92/93 ANARE. We are grateful for H. Nakamura, K. Noguchi, H. Ohotsuka and R. Horii at Hukuro Cove colony and Sue Robinson at Magnetic Island colony for their kind field assistance. $\mathbf{K}$. Nishimura and an anonymous referee provided invaluable comments on the manuscript. 


\section{References}

Brown, C. R. 1987 Energy requirements for growth and maintenance in Macaroni and Rockhopper Penguins. Polar Biol. 8: 95-102.

Croxall J. P., Prince P. A. \& Ricketts C. 1985. Relationships between prey life-cycles and the extent, nature and timing of seal and seabird predation in the Scotia Sea. In Antarctic Nutrient Cycles and Food Webs (ed. W. R. Siegfried, P. R. Condy and R. M. Laws), pp. 516-533. Springer-Verlag, Berlin.

Cooper, J. 1977 Energetic requirements for growth of the Jackass penguin. Zool. Africana 12: 201-213.

Culik, B., Woakes, A. J., Adelung, D., Wilson R. P., Coria N. R., \& Spairani H. J. 1990. Energy requirements of Adélie penguin (Pygoscelis adeliae) chicks. J. Comp. Physiol. B 160: 61-70.

Jackson, S. 1986. Assimilation efficiencies of White-chinned petrels Procellaria aequinoctialis fed different prey. Comp. Biochem. Physiol. A 85: 301-303.

Lishman, G. S. 1985 The food and feeding ecology of Adélie (Pygoscelis adeliae) and Chinstrap penguins ( $P$. antarctica) at Signy Island, South Orkney Islands. J. Zool., Lond. 205: 245-263.

Ricklefs, R. E. 1974. Energetics of reproduction in birds. In Avian Energetics (ed R.A. Paynter), pp. 152-292. Nutthall Ornithological Club, Cambridge, Massachusetts.

Ricketts, C. \& Prince, P. A. 1984. Estimation by use of field weighings of metabolic rate and food conversion efficiency in Albatross chicks. Auk 101: 790-795.

Robertson, G., Green, B., \& Newgrain, K. 1988. Estimated feeding rates and energy requirements of Gentoo Penguins, Pygoscelis papua, at Macquarie Island. Polar Biol. 9: 89-93.

Taylor, J. 1985. Ontogeny of the thermoregulation and energy metabolism in Pygoscelid penguin chicks. J. Comp. Physiol. B 155: 615-627.

Watanuki, Y., Kato, A., Mori, Y., \& Naito, Y. 1993. Diving performance of Adélie penguins in relation to food availability in fast sea-ice area: comparison between years. J. Anim. Ecol. 92: 634-646.

Williams, A. J. 1982. Chick-feeding rates of Macaroni and Rockhopper penguins at Marion Island. Ostrich 53: 129-134.

Woehler, E. J., Tierney, T.J., \& Burton, H. R. 1989. The distribution and abundance of Adélie penguins, Pygoscelis adeliae, at the Vestfold Hills, 1973. ANARE Research Notes 70: 1-41.

\section{体重と成長率を使ったアデリーペンギンの雛の餌消費量の推定}

ペンギンの眲消費は南大洋における食物連鎖の重要な部分を占める。アデリーペンギン Pygoscelis adeliae の雅の 1 日の餌消費量を，雊の体重を一定間隔で測定することによって推定する簡便な方法を紹介す る。給餉を受けない時, 雊の体重は一定速度で直線的に減少すると仮定した場合, 雊の初期体重と 1 日の成 長によって, 1 日の給餌量が推定できる。この方法によって, ほかの目的のために観察している多数の雊そ れぞれの餌消費量を，さらに撹乱することなく容易に推定できる。

綿貫 豊*，加藤明子：国立極地研究所， 画173 板橋区加賀 1-9-10

Graham Robertson: Australian Antarctic Division, Channel Highway, Kingston, Tasmania 7050, Australia.

\footnotetext{
* 現所属：北海道大学農学部応用動物学教室, 画060 札幌市北区北 9 条西 9 丁目
} 